\title{
We (do not) stand on guard for thee
}

\author{
Death by Prescription: A Father Takes on \\ His Daughter's Killer - the Multi-Billion- \\ Dollar Pharmaceutical Industry \\ Terence $\mathrm{H}$. Young MP \\ Key Porter Books; 2009. \\ 374 pp \$32.95
}

$\mathrm{T}$ he death of one's child may be the most soul-racking trauma human beings can experience. "The grief multiplies. Like an evil blooming thing," writes Terrence Young of 15-year-old daughter Vanessa's death on Mar. 19, 2000. Vanessa was taking cisapride for a diagnosis of "mild bulimia" when she collapsed in front of her father as he was reading a newspaper in the family home. Young and a neighbour administered CPR, but he then had to watch as Vanessa was transported from Oakville, Ontario to Hamilton by paramedics and as she underwent frantic, but unsuccessful resuscitation by doctors in the emergency department.

Some parents are all but destroyed by such an experience. A precious few find redemption from grief by seeking justice for others. Young, an experienced businessman and former Conservative member of the Legislative Assembly of Ontario (1995-99) with a strong religious background, knew instinctively what he had to do. "Of course I had no choice. To do any less than find out why Vanessa died would be unthinkable," he writes. But Young's journey toward justice for Vanessa has been much longer, more convoluted, and less successful than he must have hoped when he set his remarkable course.

Young learned rapidly from the Internet that cisapride was contraindicated for Vanessa, and that it had been associated with at least 80 suspicious deaths in Canada and the United States. ${ }^{1}$ He discovered that Health Canada delayed alerting doctors that cisapride

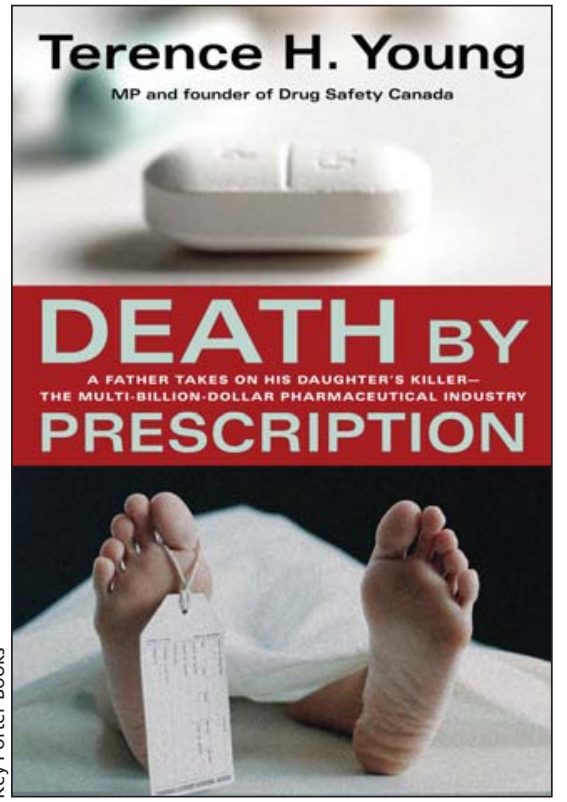

was potentially dangerous. Ignoring what friends, colleagues or family may have thought of his judgment, Young plunged into a relentless personal campaign to spare others from a similar experience.

This gripping account of his journey is highly personal. Anyone who has children will find the story as compelling as it is disturbing. At times, Death by Prescription recalls John le Carré's novel The Constant Gardener. An almost conspiratorial element enters the narrative when pharmacist Sana Sukkari, "finds a rubber glove with a finger cut off - a not-so-subtle intimidation" on her hospital desk after reporting to Health Canada her suspicion that cisapride may have been implicated in the deaths of cancer patients in the Joseph Brant Hospital in Burlington, Ont. ${ }^{2,3}$ But Young, while at times naive about science and medicine, also displays formidable analytical skills. As an experienced businessman, Young "knew I must follow the money."

Eight years of research and contemplation allow him to generalize from personal experience to a broad and freethinking critique of how the global economy promotes unwise and unethical use of prescription drugs. He describes systematic flaws in the processes of drug discovery, licensing, regulation and marketing, most referenced with detailed footnotes. Young is harshly critical of what he sees as Health Canada's lax regulatory approach and of how the federal government appears to favour drug manufacturers' economic interests over consumer protection. He believes Health Canada deliberately undermined the independence of its own expert reviewers such as Dr. Michelle Brill-Edwards, whom he quotes as saying "...it's so hard to change things at Health Canada (because people) ... refuse to believe their government is working against them." Unfortunately, the book's documentation of Health Canada's inner workings lacks detail, perhaps because of government's own secrecy. BrillEdwards' full story has not been told publicly, and perhaps it never will. ${ }^{2}$ To reform Health Canada, it would be helpful to know much more about its inner workings.

In Death by Prescription, Young describes scathingly, but persuasively, how Janssen-Ortho and its parent company Johnson \& Johnson concealed information in order to maximize cisapride sales. He argues that even the US Food and Drug Administration was kept in the dark, at the expense of additional avoidable deaths. In the wake of Vanessa's death in 2000, her grieving father is "dumbfounded" to read a Los Angeles Times exposé showing that both the manufacturer and the FDA knew as early as 1993 about cisaprideinduced dysrhythmias. ${ }^{4}$ Struggling to reconcile his Anglican faith in human goodness with the venal behaviour unearthed by his research, Young provides an almost quaintly old-fashioned explanation: "I began to realize that 
indifference could only prevail if something was missing. ... It was mercy."

Young does not spare the medical profession, either. He emphasizes that the pharmacology education of medical students is in shocking disarray, while continuing medical education for practising doctors is fatally conflicted by commercial sponsorship. He is disappointed that few doctors report adverse drug reactions and explores why they may consider it futile to file such reports to a government agency that often appears to ignore them.

Elected to Parliament in October 2008 as a Conservative representing Oakville, Young considers that Canadian parliamentarians face more stringent conflict-of-interest disclosure than doctors or academics. He decries the nefarious influence of political fundraising (especially from businesses and unions), and applauds Prime Minister Stephen Harper for instituting reforms to federal campaign finance.

Yet even as he struggled to pursue justice for Vanessa, this prominent Christian had to earn a living, partly as a government appointee adjudicating Ontario liquor and gambling licences.

But above all, Young comes across as a man of genuine conviction and real courage - exactly the kind of MP most Canadians voters say they want. In a telephone interview he described how a "very senior person in the pharmaceutical industry" asked to meet him during his first campaign for Parliament in 2007, a contest he lost in a close vote. Young claims his interlocutor suggested that "about 300 industry votes here in Oakville" might not go Conservative because he "had been hanging around with some very antiindustry people on the West Coast." (Young said this reference was to the UBC Therapeutics Initiative, an academic drug-detailing group that an industry-dominated British Columbia government task force recommended be disbanded). Young says he suggested this "senior person ... take his vote and shove it."

Asked what he now hopes to accomplish as a Member of Parliament, Young replied that he is but "one of 308 MPs." How heartwarming to hear next that he was applauded by many colleagues for supporting a New Democratic Party private member's bill intended to facilitate provision of generic antiretroviral drugs to Africa.

The issue is simple, says Young: "On one hand, you have the wealthiest companies in the world, whose CEOs each make more money than all the MPs in a Parliamentary meeting room, combined. On the other hand, you have 40 million Africans who are going to die a painful death from HIV. I would rather listen to the grandmothers supporting those people than to the drug company lobbyists." But does any MP this gutsy and forthright stand a chance of getting near the real levers of Canadian political power?

Death by Prescription has a few faults. The monikers of key protagonists vary between real names and pseudonyms, sometimes confusing even an attentive reader. Young might also have been kinder to those wonderful drugs that have profoundly improved human health, and to their discoverers and manufacturers and to the doctors who prescribe them appropriately. Certain important assertions of fact could be referenced in greater detail or more convincingly. And while Young's critique of how business interests corrupt democratic government is penetrating, he is less clear on how to fix a broken system. When asked in an interview for more concrete ideas, he replied that "I put everything I know in the book now it's up to others to do something."

He's right. Terrence Young says he made an agreement with God that if he did this painful work diligently and faithfully, he will see Vanessa again. If 307 other MPs and thousands of other Canadians read this book, the momentum to improve prescription drug regulation, promotion and utilization might become unstoppable. Then Vanessa Young's cruel and untimely death could truly be redeemed.

\section{Thomas L. Perry MD}

Department of Anesthesiology, Pharmacology \& Therapeutics University of British Columbia Vancouver, BC

\section{REFERENCES}

1. Lessons from cisapride [editorial]. CMAJ 2001;164:1269.

2. Sibbald, B. Coroner considers second cisapride inquest. CMAJ 2002;166:1075.

3. Sibbald B. Health Canada target postmarket surveillance of drugs. CMAJ 2002;166:1580

4. Willmar D. A heartburn drug, now linked to children's deaths. Los Angeles Times 2000 Dec. 20;Sect A:1 